\title{
Application of Scientific Approach by Sociology Teachers at Public Senior High Schools in Pontianak
}

\author{
Yohanes Bahari \\ Department of Sociology Education, Tanjungpura University \\ Pontianak, Indonesia \\ yohan58.yb@gmail.com
}

\begin{abstract}
This study was intended to describe the application of scientific approach by Sociology teachers at public senior high schools in Pontianak. The things described were the application of the following steps: (1) observing; (2) questioning; (3) reasoning; (4) communicating; (5) concluding and (6) inventing. The study used a descriptive quantitative survey method. Sociology teachers and the social science students of grade XII in Pontianak constituted the study population. Meanwhile, a sample of 20 Sociology teachers and 80 social science students of grade XII were taken from the population. Indirect communication technique was used as a technique of data collecting with an instrument of data collecting was a questionnaire. Quantitative descriptive percentage analysis was used to process the data. The results revealed that the application of scientific approach by Sociology teachers at public senior high schools in Pontianak was categorized as sufficient. In particular, the findings revealed that the application of all 6 steps was categorized as sufficient.
\end{abstract}

Keywords-application of scientific approach, Sociology teachers.

\section{INTRODUCTION}

The approach and method used by teachers play a very important role in determining learning outcome. Research findings of [1], [2], and [3] reveal that teaching and learning using scientific approach is more effective than that of conventional teaching approach. In the 2013 curriculum, scientific approach is used in competency-based and character-based teaching. The scientific approach is deemed a good way in developing attitude, skill and knowledge. The formation of integrated attitude, skill and knowledge would produce innovative and creative students.

The scientific approach consists of six steps, namely: (1) observing; (2) questioning; (3) reasoning; (4) communicating; (5) concluding and (6) inventing. This approach can use various learning models, such as discovery learning, projectbased learning, and problem-based learning.

Based on the initial interview held in mid-July 2016 with teachers at 10 public senior high schools in Pontianak, it was found out that they had been socialized with the approach, with the evidence being all sociology teachers at the 10 public senior high schools have already known the scientific approach. However, due to the novelty of scientific approach in the curriculum, and the fact that not every teacher has participated in the training, it is assumed that the teachers' ability in carrying out the approach would vary.
The teachers who already participated in the training admitted that it was difficult enough for them to carry out the approach since they were accustomed to apply the conventional approach. If the teachers who already participated in the training experienced difficulties in applying the approach, it is assumed that it would be much more difficult for the teachers who have not yet participated in the training.

Considering the above background and to know the application of scientific approach among Sociology teachers at public senior high schools in Pontianak, it is deemed necessary to conduct this research by selecting Sociology teachers and social science students of grade XII in Pontianak as the population. The purpose of limiting the research subjects to the teachers and students with descriptive qualitative approach is to obtain a different perspective which is supposed to be objective. Moreover, research on the perspective of teachers and students with descriptive qualitative approach itself has been frequently conducted so far.

Teaching and learning is a scientific process by the use of the scientific approach. Through the use of scientific approach, it is believed that students' attitude, knowledge, and skill would materialize. Scientific process in teaching and learning generally go through three steps, namely: opening, core and closure.

The use of scientific approach to teaching and learning is in line with the theory of learning proposed by [4], [5], and [6]. According to [4], there are four main things concerning learning. First, students only learn and develop their thoughts if they use their thoughts. Second, by doing the cognitive process in a discovery process, students would obtain sensation and intellectual satisfaction which is a kind of intrinsic appreciation. The only way for students to learn discovery techniques is when they have opportunities to discover something. Fourth, the discovery would improve students' retention. The four things above are in line with the cognitive process necessary in teaching and learning through a scientific approach

According to [5], learning is concerned with the formation or development of schema (plural schemata). The schema is a kind of mental structure or cognitive structure through which students intellectually adapt and coordinate with their surroundings [7]. Schema never stops changing. A child's schemata will eventually develop into an adult's schemata. 
The process that brings about a change in schemata is known as adaptation. The process that creates adaptation can be carried out in two ways, namely: assimilation and accommodation. Assimilation is a cognitive process whereby a person integrates stimuli in the forms of perception, concept, law, principle or new experience into the schema that already exists in their thoughts. Accommodation could consist of the formation of a new schema which suits the existing stimuli or modifying the existing schema so as to suit the existing stimuli. In the process of learning, there needs to be an equilibrium between assimilation and accommodation.

In the meantime, [8] and, [9] state that learning happens when students work or learn to handle tasks they have not yet studied, but the tasks are still within their capabilities, or the tasks are in the zone of proximal development.

According to [3], [10] and [11], scientific approach is a teaching and learning approach which is carried out through the processes of observing, questioning, experimenting, associating and communicating. Teaching and learning through scientific approach is a teaching and learning process designed in such a way so students actively construct concept, law or principle through the steps of observing (to identify or discover problems), formulating problems, forming hypothesis, collecting data with various techniques, analyzing the data, drawing conclusion and communicating the discovered concept, law or principle [12].

The scientific approach is intended to provide understanding to students in recognizing, comprehending various materials using the scientific approach. Students will be encouraged to find out for themselves from various sources through observation, not spoonfed by teachers. The purpose of this approach is to enable students to solve the problems they encounter in their daily lives [13].

Teaching and learning process through the scientific approach applies scientific principles. The scientific approach is characterized by observing, associating, discovering, verifying and explaining the truth of something [2].

Teaching and learning process is said to contain scientific process if it consists of the following characteristics: (a) Learning materials contain facts and phenomena which could be explained certain logic and reasoning, rather than based on probability, imagination, legend or myths, (b) Teachers' explanation, responses from the students are free from bias, subjective thoughts or flawed reasoning which deviates from logical thinking, (c) Encouraging and inspiring students to critically, analytically, and correctly identify, comprehend, solve problems and apply the learning materials, (d) It is based on concept, theory and empirical facts that are accountable, (e) Learning objectives are to be formulated simply and clearly; however, the system of presentation should be interesting.

In practice, scientific approach to all subjects is to be carried out through observing, questioning, reasoning, processing, presenting, concluding and inventing.

\section{METHODS}

Descriptive quantitative with survey method was the research method used (Sugyono, 2015). Sociology teachers and the social science students of grade XII in Pontianak constituted the research population. Meanwhile, a sample of 20 Sociology teachers and 80 social science students of grade XII were taken from the population. Indirect communication technique was used as a technique of data collecting, with the instrument of data collecting is a questionnaire. Quantitative descriptive percentage analysis was used as the technique of data analysis. Criterion/ indicator of questionnaire outcome is as follows: $71 \%-100 \%=$ good, $41 \%-70 \%=$ sufficient and $0 \%-$ $40 \%=$ bad.

\section{RESULTS AND DISCUSSIONS}

\section{A. Results}

Based on the results of the questionnaire administered to 20 Sociology teachers and 80 social science students of grade XII, the following answers were obtained as depicted in the tables below:

1) Application of Observation on six steps in Teaching and Learning

TABLE I. ANSWERS GIVEN By TEACHERS AND STUDENTS ABOUT THE APPLICATION OF OBSERVATION THE STEPS.

\begin{tabular}{|c|c|c|c|c|c|c|}
\hline \multirow{2}{*}{$\begin{array}{c}\text { Question } \\
\text { No }\end{array}$} & \multicolumn{6}{|c|}{ Respondent's Answers } \\
\cline { 2 - 7 } & \multicolumn{2}{|c|}{ Always } & \multicolumn{2}{c|}{ Sometimes } & \multicolumn{2}{c|}{ Never } \\
\hline & $\mathrm{T}$ & $\mathrm{S}$ & $\mathrm{T}$ & $\mathrm{S}$ & $\mathrm{T}$ & $\mathrm{S}$ \\
\hline 1 & 8 & 39 & 10 & 38 & 2 & 3 \\
\hline 2 & 9 & 38 & 10 & 35 & 1 & 7 \\
\hline 3 & 9 & 40 & 10 & 36 & 1 & 4 \\
\hline Total & 26 & 117 & 30 & 109 & 4 & 14 \\
\hline Percentage & \multicolumn{2}{|c|}{$43.3 \% /$} & \multicolumn{2}{|c|}{$50 \% /$} & \multicolumn{2}{|c|}{$6.7 \% /$} \\
$(\%)$ & $48.8 \%$ & \multicolumn{2}{|c|}{$45.4 \%$} & \multicolumn{2}{c|}{$5.8 \%$} \\
\hline Average & \multicolumn{2}{|c|}{$46.05 \%$} & \multicolumn{2}{c|}{$47.7 \%$} & \multicolumn{2}{c|}{$6.25 \%$} \\
\hline
\end{tabular}

2) Application of Questioning on six steps in Teaching and Learning

TABLE II. ANSWERS GIVEN BY TEACHERS AND STUDENTS ABOUT THE APPLICATION OF QUESTIONING THE STEPS.

\begin{tabular}{|c|c|c|c|c|c|c|}
\hline \multirow{2}{*}{ Question No } & \multicolumn{6}{|c|}{ Respondent's Answers } \\
\cline { 2 - 7 } & \multicolumn{2}{|c|}{ Always } & \multicolumn{2}{c|}{ Sometimes } & \multicolumn{2}{c|}{ Never } \\
\hline & $\mathrm{T}$ & $\mathrm{S}$ & $\mathrm{T}$ & $\mathrm{S}$ & $\mathrm{T}$ & $\mathrm{S}$ \\
\hline 1 & 11 & 43 & 9 & 32 & 0 & 5 \\
\hline 2 & 13 & 39 & 6 & 36 & 1 & 5 \\
\hline 3 & 12 & 42 & 7 & 37 & 1 & 1 \\
\hline Total & 36 & 124 & 9 & 105 & 2 & 11 \\
\hline Percentage & \multicolumn{2}{|c|}{$60 \% /$} & \multicolumn{2}{|c|}{$36.7 \% /$} & $3.3 \% /$ \\
$(\%)$ & $51.7 \%$ & \multicolumn{2}{|c|}{$43.7 \%$} & $4.6 \%$ \\
\hline Average & \multicolumn{3}{|c|}{$55.85 \%$} & \multicolumn{2}{c|}{$40.2 \%$} & $3.95 \%$ \\
\hline
\end{tabular}


3) Application of Reasoning on six steps in Teaching and Learning

TABLE III. ANSWERS GIVEN BY TEACHERS AND STUDENTS ABOUT THE APPLICATION OF REASONING THE STEPS.

\begin{tabular}{|c|c|c|c|c|c|c|}
\hline \multirow{2}{*}{ Question No } & \multicolumn{6}{|c|}{ Respondent's Answers } \\
\cline { 2 - 7 } & \multicolumn{2}{|c|}{ Always } & \multicolumn{2}{|c|}{ Sometimes } & \multicolumn{2}{|c|}{ Never } \\
\hline & $\mathrm{T}$ & $\mathrm{S}$ & $\mathrm{T}$ & $\mathrm{S}$ & $\mathrm{T}$ & $\mathrm{S}$ \\
\hline 1 & 8 & 40 & 11 & 39 & 1 & 1 \\
\hline 2 & 9 & 41 & 9 & 39 & 2 & 0 \\
\hline 3 & 10 & 38 & 9 & 39 & 1 & 3 \\
\hline Total & 27 & 11 & 29 & 11 & 4 & 4 \\
& & 9 & \multicolumn{3}{c|}{$48.3 \% /$} & $6.7 \% /$ \\
\hline Percentage & $45 \% /$ & $48.8 \%$ & $1.6 \%$ \\
\hline (\%) & $49.6 \%$ & \multicolumn{3}{|c|}{$48.55 \%$} & $4.15 \%$ \\
\hline Average & $47.3 \%$ & \multicolumn{6}{|c|}{} \\
\hline
\end{tabular}

4) Application of Communicating on six steps in Teaching and Learning

TABLE IV. ANSWERS GIVEN BY TEACHERS AND STUDENTS ABOUT THE APPLICATION OF COMMUNICATING THE STEPS.

\begin{tabular}{|c|c|c|c|c|c|c|}
\hline \multirow{2}{*}{ Qu } & \multicolumn{6}{|c|}{ Respondent's Answers } \\
\cline { 2 - 7 } estion No & \multicolumn{3}{|c|}{ Always } & \multicolumn{2}{c|}{ Sometimes } & \multicolumn{2}{c|}{ Never } \\
\hline & $\mathrm{T}$ & $\mathrm{S}$ & $\mathrm{T}$ & $\mathrm{S}$ & $\mathrm{T}$ & $\mathrm{S}$ \\
\hline 1 & 11 & 45 & 8 & 33 & 1 & 2 \\
\hline 2 & 10 & 43 & 9 & 33 & 1 & 4 \\
\hline 3 & 12 & 46 & 7 & 33 & 1 & 1 \\
\hline Total & 33 & 134 & 24 & 99 & 3 & 7 \\
\hline Percentage (\%) & \multicolumn{3}{|c|}{$55 \% /$} & \multicolumn{2}{c|}{$40 \% /$} & \multicolumn{2}{c|}{$5 \% /$} \\
& $55.8 \%$ & $41.3 \%$ & $2.9 \%$ \\
\hline Average & \multicolumn{3}{|c|}{$55.4 \%$} & $40.65 \%$ & $3.95 \%$ \\
\hline
\end{tabular}

5) Application of Concluding on six steps in Teaching and Learning

TABLE V. ANSWERS GIVEN BY TEACHERS AND STUDENTS ABOUT THE APPLICATION OF CONCLUDING THE STEPS.

\begin{tabular}{|c|c|c|c|c|c|c|}
\hline \multirow{3}{*}{$\begin{array}{l}\text { Question } \\
\text { No }\end{array}$} & \multicolumn{6}{|c|}{ Respondent's Answers } \\
\hline & \multicolumn{2}{|c|}{ Always } & \multicolumn{2}{|c|}{ Sometimes } & \multicolumn{2}{|c|}{ Never } \\
\hline & $\mathrm{T}$ & $\mathrm{S}$ & $\mathrm{T}$ & $\mathrm{S}$ & $\mathrm{T}$ & $\mathrm{S}$ \\
\hline 1 & 11 & 44 & 8 & 34 & 1 & 2 \\
\hline 2 & 12 & 41 & 7 & 36 & 1 & 3 \\
\hline 3 & 11 & 42 & 8 & 36 & 1 & 2 \\
\hline Total & 34 & 127 & 23 & 106 & 3 & 7 \\
\hline $\begin{array}{c}\text { Percentage } \\
(\%)\end{array}$ & \multicolumn{2}{|c|}{$\begin{array}{l}56.7 \% / \\
52.9 \%\end{array}$} & \multicolumn{2}{|c|}{$\begin{array}{l}38.3 \% / \\
44.2 \%\end{array}$} & \multicolumn{2}{|c|}{$\begin{array}{l}5 \% / \\
2.9 \% \\
\end{array}$} \\
\hline Average & \multicolumn{2}{|c|}{$54.8 \%$} & \multicolumn{2}{|c|}{$41.25 \%$} & \multicolumn{2}{|c|}{$3.95 \%$} \\
\hline
\end{tabular}

6) Application of Inventing on six steps in Teaching and Learning

TABLE VI. 6 ANSWERS GIVEN By TEACHERS AND STUDENTS ABOUT THE APPLICATION OF INVENTING THE STEPS.

\begin{tabular}{|c|c|c|c|c|c|c|}
\hline \multirow{2}{*}{ Question No } & \multicolumn{6}{|c|}{ Respondent's Answers } \\
\cline { 2 - 7 } & \multicolumn{2}{|c|}{ Always } & \multicolumn{2}{c|}{ Sometimes } & \multicolumn{2}{c|}{ Never } \\
\hline & $\mathrm{T}$ & $\mathrm{S}$ & $\mathrm{T}$ & $\mathrm{S}$ & $\mathrm{T}$ & $\mathrm{S}$ \\
\hline 1 & 9 & 38 & 10 & 38 & 1 & 1 \\
\hline 2 & 10 & 37 & 9 & 37 & 1 & 1 \\
\hline 3 & 9 & 38 & 11 & 38 & 0 & 2 \\
\hline Total & 28 & 113 & 30 & 113 & 2 & 4 \\
\hline Percentage & \multicolumn{2}{|c|}{$46.7 \% /$} & \multicolumn{2}{|c|}{$50 \% /$} & \multicolumn{2}{|c|}{$3.3 \% /$} \\
$(\%)$ & $47.1 \%$ & \multicolumn{2}{|c|}{$51.2 \%$} & \multicolumn{2}{c|}{$1.7 \%$} \\
\hline Average & \multicolumn{2}{|c|}{$46.9 \%$} & \multicolumn{2}{|c|}{$50.6 \%$} & \multicolumn{2}{|c|}{$2.5 \%$} \\
\hline
\end{tabular}

\section{B. Discussion}

1) Application of Observation Approach in Teaching and Learning

The questionnaire results show that an average of $46.05 \%$ of teachers and students always applied observation approach, $47.7 \%$ applied it sometimes, and only $6.25 \%$ never applied it.

Based on the respondent's answers to the questionnaire, in general, the application of observation approach only ranges between $41 \%-70 \%$. Such percentage range shows that the application of observation approach is categorized as sufficient.

Therefore, the data show that the majority of Sociology teachers at public senior high schools in Pontianak already applied observation approach; however, it is categorized as sufficient only. For that reason, further training is necessary in order to increase the application of observation approach.

2) Application of Questioning Approach in Teaching and Learning

The questionnaire results show that an average of $55.85 \%$ of teachers and students always applied questioning approach, $40.2 \%$ applied it sometimes, and only $3.9 \%$ never applied it.

Based on the respondent's answers to the questionnaire, in general, the application of questioning approach only ranges between $41 \%-70 \%$. Such percentage range shows that the application of questioning approach is categorized as sufficient.

Therefore, the data show that the majority of Sociology teachers at public senior high schools in Pontianak already applied questioning approach; however, it is categorized as sufficient only. For that reason, further training is necessary in order to increase the application of the questioning approach.

3) Application of Reasoning Approach in Teaching and Learning

The questionnaire results show that an average of $47.3 \%$ of teachers and students always applied reasoning approach, $48.55 \%$ applied it sometimes, and only $4.15 \%$ never applied it.

Based on the respondent's answers to the questionnaire, in general, the application of reasoning approach only ranges 
between $41 \%-70 \%$. Such percentage range shows that the application of reasoning approach is categorized as sufficient.

Therefore, the data show that the majority of Sociology teachers at public senior high schools in Pontianak already applied reasoning approach; however, it is categorized as sufficient only. For that reason, further training is necessary in order to increase the application of thereasoning approach.

\section{4) Application of Communicating Approach in Teaching and Learning}

The questionnaire results show that an average of $55.4 \%$ of teachers and students always applied communicating approach, $40.65 \%$ applied it sometimes, and only $3.95 \%$ never applied it.

Based on the respondent's answers to the questionnaire, in general, the application of communicating approach only ranges between $41 \%-70 \%$. Such percentage range shows that the application of communicating approach is categorized as sufficient.

Therefore, the data show that the majority of Sociology teachers at public senior high schools in Pontianak already applied communicating approach; however, it is categorized as sufficient only. For that reason, further training is necessary in order to increase the application of the concluding approach.

\section{5) Application of Communicating Approach in Teaching} and Learning

The questionnaire results show that an average of $54.8 \%$ of teachers and students always applied concluding approach, $41.25 \%$ applied it sometimes, and only $3.95 \%$ never applied it.

Based on the respondent's answers to the questionnaire, in general, the application of concluding approach only ranges between $41 \%-70 \%$. Such percentage range shows that the application of concluding approach is categorized as sufficient.

Therefore, the data show that the majority of Sociology teachers at public senior high schools in Pontianak already applied concluding approach; however, it is categorized as sufficient only. For that reason, further training is necessary in order to increase the application of the concluding approach.

6) Application of Inventing Approach in Teaching and Learning

The questionnaire results show that an average of $46.9 \%$ of teachers and students always applied inventing approach, $50.6 \%$ applied it sometimes, and only $2.5 \%$ never applied it.

Based on the respondent's answers to the questionnaire, in general, the application of concluding approach only ranges between $41 \%-70 \%$. Such percentage range shows that the application of concluding approach is categorized as sufficient.

Therefore, the data show that the majority of Sociology teachers at public senior high schools in Pontianak already applied inventing approach; however, it is categorized as sufficient only. For that reason, further training is necessary in order to increase the application of the inventing approach.

\section{CONCLUSION AND RECOMMENDATION}

\section{A. Conclusion}

Based on the results and discussion, the general conclusion of this study is that the majority of Sociology teachers at public senior high schools in Pontianak have sufficiently applied scientific approach where they have successfully applied observation, questioning, reasoning, communicating, concluding and inventing six steps..

\section{B. Recommendation}

Based on the above research conclusions, the researcher puts forward the following recommendations:

1. It is still necessary for the Sociology teachers at public senior high schools in Pontianak to promote the application of scientific approach so that better results could be achieved.

2. For the application of the scientific approach to achieve the best results, it is necessary for the teachers to participate in further training, fostering, and development.

3. The Sociology teachers at public senior high schools in Pontianak who have always applied scientific approach should be encouraged to continue applying it.

4. The Sociology teachers at public senior high schools in Pontianak who have not fully applied scientific approach should be fostered through various opportunities, for example through teachers discussion forum (MGMP), through teaching workshops, and scientific approach training.

\section{REFERENCES}

[1] John. Hattie, Developing Potentials for Learning: Evidence, Assessment and Progress, Stockhlom, Visible learning Lab, University of Auckland, New Zealand, 2008,p 161-236 .

[2] Kementerian Pendidikan dan Kebudayaan, Konsep Pendekatan Saintifik,, Jakarta, 2013, p 42.

[3] Fadillah, Implementasi Kurikulum 2013 dalam Pembelajaran SD/MI, SMP/MTs, dan SMA/MA, Yogyakarta, Ar-Ruzz Media, 2014, p 16.

[4] J.S. Bruner, The Process of Education, New York, Vintage Book, 1960, p 69-80

[5] Jean. Piaget, The Equilibration of Cognitive Structures: The Central Problem of Intellectual Development, University of Chicago Press, Chicago, 1985, p 122-123

[6] A.A. Carin and R.B. Sund, Teaching Science Through Discovery, Third Editional, Charles Merril Publishing Company, Columbus, Ohio, 1975, p 37-60.

[7] A.L. Baldwin. Theories of Child Development, Chicago, John Willey \& Sons, Inc, 1967, p 618.

[8] S.A. Ambrose. M.W. Bridges, M. Di Pietro, M.C. Lovett and M.K. Norman, How Learning Works: Seven Research Based Principles for Smart Teaching, San Fransisco, CA: Jossey Bass, 2010, p 188.

[9] M. Nur dan Wikandari. Pengajaran Berpusat Kepada Siswa dan Pendekatan Konstruktivistik dalam Pengajaran, Surabaya, Universitas Negeri Surabaya, 2000, p 2. 
[10] Mulyasa, E,Pengembangan dan Implementasi Kurikulum 2013, Bandung: Remaja Rosdakarya, 2013, p 7.

[11] Hamzah dan Muhamad Nurdin, Belajar dengan Pendekatan PAIKEM, Jakarta: Bumi Aksara, 2013, p 174.

[12] Daryanto, Pembelajaran Tematik, Terpadu, Terintegrasi (Kurikulum 2013), Yogyakarta, Gava Media, 2014, p 41.

[13] Syaiful. Sagala. Konsep dan Makna Pembelajaran, Bandung, Alfabeta, 2013, p 12. 